\title{
Effective Learning for Early Childhood during Global Pandemic
}

\author{
Mohammad Fauziddin', Diana Mayasari², Lussy Midani Rizki3
}

DOI: $10.35445 /$ alishlah.v13i1. 458

\begin{abstract}
Info Artikel
Abstract

Keywords:

Parents

Effective Learning

Strategies

Online media

Several previous research studies stated that parents have a big role in implementing learning during a global pandemic, which is well-known with COVID-19. This research aims to review the role and strategies of parents in assisting children to learn during the pandemic. The research method is a literature study by selecting various articles of research results according to the research study. The results of the study indicate that effective learning can be done by recognizing children's learning styles, creating a positive environment, creating various learning methods with teacher coordination. In addition to parents, the government and teachers also have a stake in the success of practical learning in achieving learning goals: online learning through instructional videos, assignments tailored to learning conditions at home, and preparing learning tools to be carried out at home. These findings provide valuable insights for parents to be alert and more creative in creating effective learning.
\end{abstract}

Kata kunci:

Orang tua

Strategi Belajar efektif

Media Online

\begin{abstract}
Abstrak
Beberapa hasil penelitian menyebutkan bahwa orang tua memiliki andil besar dalam pelaksanaan pembelajaran di masa pendemi covid-19. Tujuan penelitian ialah meninjau peran orang tua dalam mendampingi anak belajar selama pandemi berlangsung. Penelitian ini menggunakan metode studi literatur dengan menyeleksi berbagai artikel hasil penelitian yang sesuai dengan kajian penelitian. Hasil penelitian menyebutkan bahwa pembelajaran yang efektif bisa dilakukan dengan cara mengenal gaya belajar anak, menciptakan lingkungan yang positif, membuat berbagai metode pembelajaran dengan koordinasi guru. Selain orang tua, pemerintah dan guru juga memiliki andil dalam mensukses pembelajaran yang efektif dalam mencapai tujuan pembelajaran, seperti: pembelajaran online melalui video pembelajaran, tugas yang disesuaikan dengan kondisi belajar di rumah, menyiapkan alat pembelajaran untuk dilaksanakan dirumah. Hasil penelitian ini diharapkan mampu menginspirasi para orang tua untuk sigap dan lebih kreatif dalam menciptakan pembelajaran yang efektif untuk anak usia dini.
\end{abstract}

\footnotetext{
${ }^{1}$ Universitas Pahlawan Tuanku Tambusai, Riau, Indonesia

Email: mfauziddin@gmail.com

2 Sekolah Tinggi keguruan dan Ilmu Pendidikan PGRI Jombang, Jawa Timur, Indonesia

Email: dianamayasari.stkipjb@gmail.com

3 Universitas Pahlawan Tuanku Tambusai, Riau, Indonesia

Email: lussymidani@gmail.com
} 


\section{PENDAHULUAN}

Pandemi covid 19 telah mengubah tataran kehidupan dari berbagai bidang, seperti kesehatan, pendidikan, sosial, budaya, agama, ekonomi dan tatakelola kelangsungan hidup manusia. Tidak dapat dipungkiri pengubahan tersebut sebagai upaya mempertahankan hidup. Dampak yang paling terasa selain bidang kesehatan adalah pendidikan. Pemerintah sebagai pemegang kebijakan terus berupaya agar pendidikan dapat terus berlangsung meski wabah corona virus disease (COVID-19) terus meningkat dan tidak diketahui kapan berakhir. Walaupun vaksin telah ditemukan, namun belum diketahui juga keakuratannya dalam mencegah penyerang virus tersebut.

Dengan adanya kondisi pandemic, pembelajaran dilakukan dari rumah secara daring dalam rangka pencegahan COVID-19 dan terjadi perubahan sesuai dengan kondisi daerah di Indonesia (Kemdikbud, 2020). Hal ini mewajibkan guru dan instansi pendidikan untuk menyusun pembelajaran secara daring. Dalam rangka mencegah penyebaran COVID-19, aktivitas pembelajaran dilaksanakan di rumah melalui aplikasi yang tersedia, seperti: video conference, digital document atau sarana lainnya yang memadai proses pembelajaran daring.

Pembelajaran daring ialah pembelajaran menggunakan sumber teknologi serta media lain yang berkembang saaat ini (Pudyastuti \& Budiningsih, 2021). Hasil penelitian Wargadinata et al., (2020) menunjukkan pembelajaran daring pada saat pandemic dapat membuat pembelajaran efektif, karena pembelajaran menggunakan aplikasi seperti whatsapp yang terdapat interaktif antara anak dan tenaga pengajar dan dapat berbagi file, powerpoint, miscrosoft word, voice notes, video dan sumber belajar yang lain sehingga pembelajaran menjadi optimal dan efektif. Di awal pencetusan model pembelajaran ini tentu banyak mengalami pro dan kontra. Pembelajaran dilaksanakan secara daring, sedangkan guru dan orang tua belum siap teruatama sarana dan prasana, pembelajaran daring kurang efektif disebabkan pengajar hanya menyampaikan materi padahal praktek sangatlah penting (Ayuni et al., 2021; Pudyastuti \& Budiningsih, 2021; Sari, 2020). Pemerintah mengeluarkan kebijakkan pelaksannan pembelajaran secara daring untuk mencegah perkembangan dan penyebaran Covid-19. Salah satu tawaran solusi yang banyak dilakukan adalah yakni melalui pengembangan teknologi yang sangat pesat, yakni google classroom, google meeting, aplikasi zoom, whatsapp, dan berbagai aplikasi sebagai pengganti pertemuan agar tetap bisa bertemu dengan guru dan teman-teman. Model pembelajaran ini juga berlaku bagi PAUD sebagai salah satu tahap yang dilewati oleh anak sebelum menghadapi tahapan pendidikan lanjutan. Pendidikan anak usia dini ialah tahap yang potensial sebagai dasar pada tahap perkembangan berikutnya (Rahmi, 2020).

Pendidikan anak usia dini diatur Undang-undang Republik Indonesia Nomor 20 tahun 2003 tentang sistem pendidikan pada bagian ke tujuh pasal 28, yaitu: "1) PAUD diselenggarakan sebelum jenjang pendidikan dasar, 2)PAUD dapat diselenggarakan melalui jalur pendidikan formal, nonformal, dan/atau informal, 3) selain itu, PAUD pada jalur pendidikan formal berbentuk Taman Kanak-kanak (TK), Raudatul Athfal (RA), atau bentuk lain yang sederajat, 4) PAUD pada jalur pendidikan nonformal berbentuk Kelompok Bermain (KB), Taman Penitipan Anak (TPA), atau bentuk lain yang sederajat, 5) PAUD pada jalur pendidikan informal berbentuk pendidikan keluarga atau pendidikan yang diselenggarakan oleh lingkungan, 6) Serta ketentuan mengenai pendidikan anak usia dini sebagaimana dimaksud dalam ayat (1), ayat (2), ayat (3), dan ayat (4) diatur lebih lanjut dengan Peraturan Pemerintah” (Pemerintah Republik Indonesia, 2003).

Berdasarkan sistem pendidikan tersebut, salah satu bentuk penyelenggaraan pendidikan anak usia dini adalah dalam keluarga dan diselenggarakan oleh lingkungan. Untuk itu, pelaksanaan pendidikan bagi anak usia dini tidak terlepas dari beberapa peran, yaitu: orang tua, keluarga, dan lingkungan masyarakat sebagai tempat tinggal untuk mengenalkan pendidikan sosial. Jika dikaitkan dengan pembelajaran pandemic tentu peran tersebut semakin besar. Hal ini dikarenakan minimnya proses tatap muka yang dilakukan disekolah. Bahkan sekolah telah membuat kurikulum darurat yang digunakan untuk melaksanakan pembelajaran di masa pandemi dengan memaksimalkan keterlibatan orang tua dan keluarga. Hal ini tentu memunculkan masalah, yakni masalah bagi anak 
dan orang tua terkait pembelajaran yang berlangsung, masalah jaringan internet, masalah bagi pendidik, dan masalah kesehatan (Pramana, 2020).

Kondisi ini menuntut para pengajar untuk berinovasi dalam berbagai aspek penyelenggaraan pendidikan, baik itu metode, media dan pengembangan teknologi informasi untuk meminimalisir permasalahan dengan menciptakan pembelajaran yang efektif. Pembelajaran efektif didefinisikan sebagai suatu pembelajaran yang berhasil mencapai tujuan belajar anak yang diharapkan oleh guru. Pembelajaran efektif ialah faktor penting dalam menentukan keberhasilan anak dalam proses pembelajaran, sehingga menjadi hal yang penting bagi seorang pendidik dalam meningkatkan mutu pembelajaran (Daulae, 2014).

Penelitian Muhdi et al., (2020) kebijakan dalam pembelajaran anak usia dini sudah efektif. Namun penerapan kebijakan pembelajaran daring pada anak usia dini mengalami kendala ketika diaplikasikan di lapangan seperti: kemampuan guru, kemampuan oran tua, kemampuan ekonomi, kendala prasarana, dan pedagogik. Senada dengan penelitian Gayatri (2020) melalui literature review menunjukkkan bahwa orang tua dan guru memiliki kendala dalam mengatur anak-anak, kesiapan dalam memanfaatkan teknologi dan materi pembelajaran, keyakinan serta sikap orang tua tentang pembelajaran daring yang menggunakan aplikasi atau software, orang tua harus siap menyiapkan waktu mendampingi anak, komunikasi sangat penting antara orang tua dan guru dalam mendukung pembelajara daring selama covid-19. Sedangkan hasil penelitian Nurdin \& Anhusadar, (2020) yaitu banyaknya guru PAUD yang mengalami kesulitan ketika menggunakan atau menjalakan aplikasi pembelajaran daring, sehingga pembelajaran daring belum berjalan dengan efektif.

Dong et al., (2020) dalam hasil penelitiannya bahwa pembelajaran anak usia dini dalam pendemi covid-19, terdapat 92,7\% sebagian orang tua melaporkan bahwa anak-anak memiliki pengalaman belajar secara daring selama pandemi, dan 84,6\% menghabiskan waktu kurang dari setengah jam. Kemudian 43,1 \% orang tua menunjukkan bahwa anak mereka belajar online sekali dan 18,4\% hanya beberapa kali. Namun pada hasil penelitian ini implementasi pembelajaran daring kurang efektif bagi orang tua Tionghoa. Hal ini disebabkan membuat orang tua kesulitan dalam mengatur anak-anak, fasilitas yang kurang memadai, dan kurangnya pengetahuan orang tua soal pembelajaran daring.

Berdasarkan beberapa hasil penelitian di atas terdapat kendala dalam pelaksanaan pembelajaran daring, maka keterbaruan dalam penelitian ini adalah kajian literature mengenai pembelajaran efektif untuk anak usia dini pada pandemi global. Tujuan penelitian akan mendeskripsikan berbagai cara belajar efektif anak usia dini di masa pandemi global. Pada hasil penelitian diharapkan dapat digunakan sebagai acuan dalam pelaksanaan pembelajaran bagi PAUD dalam menghadapi pandemic covid-19, khususnya bagi guru, orang tua dan praktisi pendidikan.

\section{METODE}

Menggunakan Pendekatan kualitatif deskriptif, jenis penelitian kepustakaan (library research). Library research merupakan cara mengumpulkan data pustaka, mengolah bahan penelitian, dan membaca (Zed, 2008). Sumber acuan kepustakaan yang dapat digunakan dalam penelitian beragam yaitu buku teks, artikel jurnal, periodical, yearbook, bulletin, annual review, recent advance, bibliografi, handbook, dan manual(Anshori \& Iswati, 2009). Penelitian ini menggunakan sumber kepustakaannya yaitu artikel jurnal nasional ataupun internasional dan buku. Menggunakan Teknik analisis data kualitatif. Hal ini dilakukan supaya dapat menjabarkannya secara mendalam. Secara rinci prosedur penelitian pada gambar 1. 


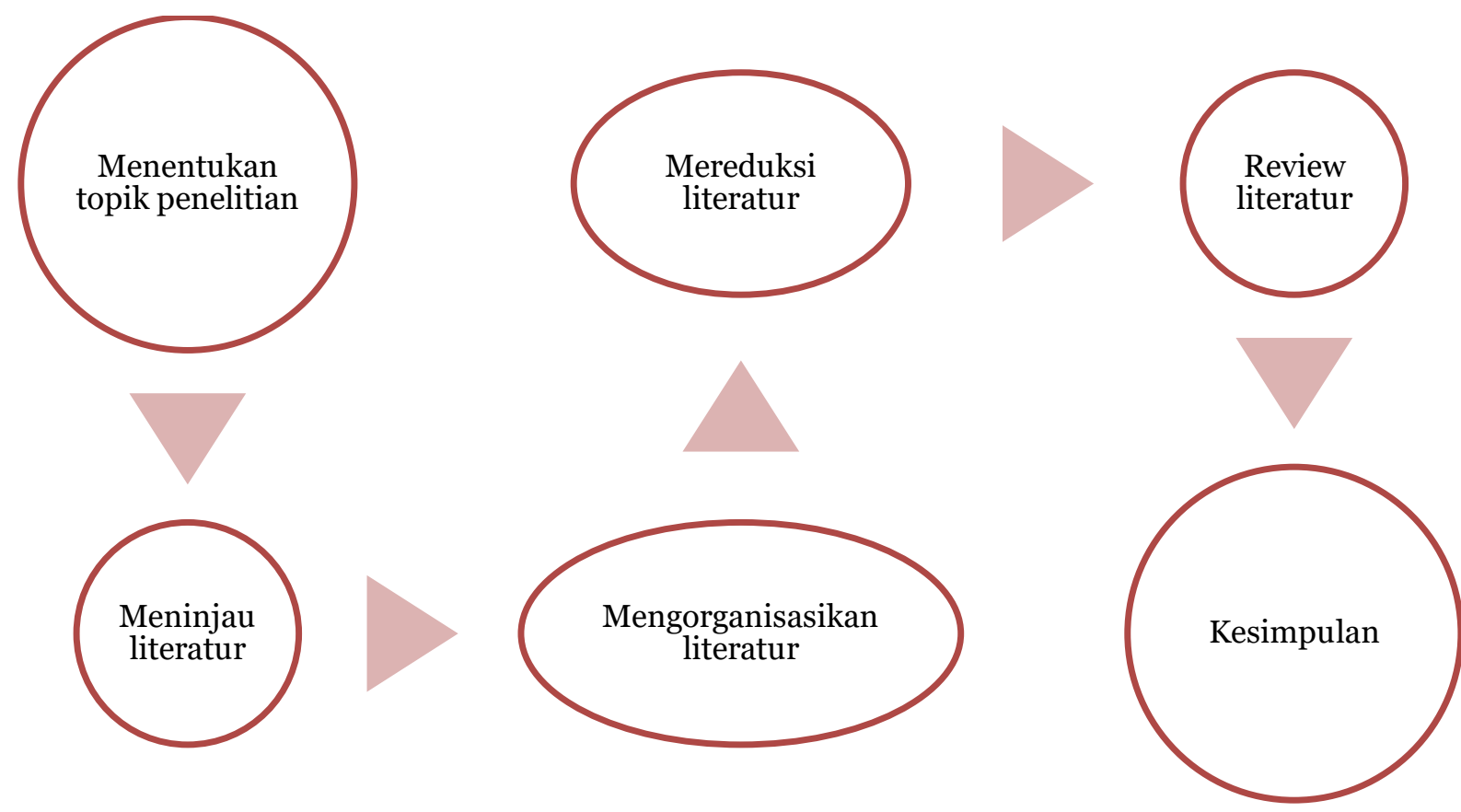

\section{Gambar 1. Langkah-langkah Penelitian}

\section{HASIL PENELITIAN DAN PEMBAHASAN}

\section{Belajar di rumah dengan panduan orang tua}

Masa pandemi covid-19 menuntut sekolah melaksanakan pembelajaran dalam jaringan (daring) merupakan salah satu upaya pencegahan penularan wabah covid-19. Ahsani (2020) menjelaskan adanya peran orang tua ketika mendampingi belajar, yaitu: (1) mengenal gaya belajar anak, yakni dengan berbagai cara, seperti: menggunakan banyak gambar dari pada kata-kata, menggunakan alat peraga, membuat kenyamanan anak dengan cara menata ruangan dengan hasilhasil karya anak, belajar melalui film yang bermanfaat untuk kehidupan atau perkembangan anak, intonasi dalam menyampaikan informasi pada anak sebaiknya menggunakan intonasi yang tepat, belajar dengan teknik bercerita; (2) menyiapkan lingkungan belajar lingkungan belajar anak yang nyaman dengan menggunakan metode bercerita, bermain, diskusi, dan metode demontrasi. Ahsani (2020) juga menjelaskan bahwa setiap metode memiliki kelemahan dan kelebihan, sehingga diharapkan menggabungkan berbagai metode tersebut dalam pelaksanaan pendampingan belajar di rumah selama masa pendemi.

Lilawati (2020) menyebutkan bahwa orang tau memiliki peran yang vital dalam pendampingan belajar di masa pandemi khususnya bagi anak usia dini dengan berperan dalam memotivasi anak selama pembelajaran di rumah. Hasil penelitiannya menyebutkan bahwa belajar di rumah dengan kerjasama orang tua dan anak tidak mengirangi tingkat pencapaian tujuan pembelajaran. Pengerjaan tugas di rumah yang dibantu oleh orang tua dirasa lebih efektif dan menjadi solusi pembelajaran daring di masa pandemi. Adanya implikasi ibu atau ayah dalam mendampingi proses belajar dari rumah dapat berupa kegiatan sebagai berikut: membantu mengerjakan tugas anak disesuaikan dengan porsi kemampuan anak agar tetap dapat diukur, sebagai tempat belajar anak pengganti kegiatan bertatap muka di sekolah, menjelaskan materi pembelajaran dengan simple dan mudah, adanya respon yang baik terhadap pembelajaran dari sekolah, selain itu menjadi pendamping anak dalam membentuk karekter yang baik selama pembelajaran di rumah, dan tanggap berkarya sebagai hasil akhir dari pembelajaran (Yulianingsih et al., 2020).

Kelemahan dengan adanya pendampingan ibu/ayah dalam proses pembelajaran daring, yakni banyak yang tidak up date lagi dengan teknologi dan informasi atau penggunaan media online 
seperti hp dan laptop, selain itu masalah jaringan internet disetiap daerah memiliki jangkauan sinyal yang berbeda-beda, sehingga kendala ini akan mempengaruhi proses pembelajaran dengan menggunakan kemajuan sistem teknologi informasi yang bergantung pada internet. Cahyati \& Kusumah (2020) menyebutkan lbeih jauh bahwa sebanyak 34\% guru yang sudah senior tidak lagi cekatan dan mampu mengikuti pengembangan teknologi informasi. Disamping itu dia juga menyebutkan hasil penelitiannya sebagian orang tua mengeluhkan pengeluaran internet yang semakin besar. Sisi positif yang dapat diambil dari pembelajaran yang didampingi oleh orang tua adalah adanya kelekatan orang tua dengan anak serta dapat mengobservasi secara langsung perkembangan anak.

Situasi pembelajaran dari rumah ini memang dirasa tidak mudah bagi guru, orang tua, ataupun anak. Rohayani (2020) menyebutkan adanya kerjasama inisiatif Parenting for lifelong healt, UNICEF menyarankanhal yang dapat dilakukan ibu dan ayah dalam mendampingi anak pada pandemic, seperti: 1) menciptakan waktu yang berkualitas antara anak, ibu ataupun ayah. Tetapkan jadwal berkegiatan dengan anak, minta anak memilih jenis kegiatan, memunculkan berbagai ide kegiatan, 2) tetap berpikir positif selama pandemi berlangsung untuk menambah imunfokus pada perilaku yang orang tua inginkan, pengaturan nada suara, memberikan pujian pada anak, tetap realistis, membantu anak untuk tetap dekat dengan teman-temanya, 3) buat jadwal, yang disepakati oleh anak agar proses belajar lebih tertata dan disiplin, pembuatan jadwal ini dilakukan dengan fleksibel namun konsisten 4) mengatasi perilaku kurang baik dengan member contoh dan bekerja sama dengan lingkungan tempat tinggal, 5) mampu mengelola emosi pada anak, 6) adanya forum yang membahas pembelajaran selama covid -19 .

\section{Melaksanakan pembelajaran online}

Dalam sebuah metode pembelajaran tentu memiliki kekurangan dan kelebihan. Rahmi (2020) menyebutkan kelebihan yang didapatkan, yakni fleksibilitas waktu, tempat, kecepatan pemahaman pembelajaran, standarisasi pembelajaran memiliki kualitas yang sama, pembelajaran didesain agar siswa lebih mudah memahami isi pelajaran, kecepatan distribusi, ketersediaan sesuai permintaan, otomatisasi proses administrasi. Kekurangan yang dimiliki adalah self learning, anggaran, aplikasi yang tidak sesuai, tidak semua materi dapat dijelaskan melalui media online, guru tidak bisa memantau secara langsung proses belajar. Pembelajaran teknologi di masa pandemic ini tidak bisa kita hentikan sehingga sebagai seorang pendidik maupun orang tua harus sigap dalam perkembangan teknologi. Pada kondisi covid ini tentu guru harus menggunakan berbagai cara agar proses pembelajaran online efektif dari pembelajaran yang lain dalam kondisi saat ini. Fase usia golden age ini akan mempengaruhi perkembangan motorik halus dan kognitif anak, sehingga harus dipilih media online yang tepat, seperti pembuatan video pembelajaran. Begitu juga orang tua harus mampu mengikuti perkembangan teknologi agar mampu mendampingi anak dengan maksimal. Selain itu Rahmi (2020) menyebutkan bahwa keputusan pemerintah melalui Kementerian Agama ternyata sangat efektif baik secara teoretis maupun praktis dalam bentuk pemahaman guru. Selain itu adanya pembelajaran online memberikan kemudahan dalam pencapaian tujuan pendidikan. Disamping itu guru PAUD akan lebih produktif lagi dalam membuat media pembelajaran online dapat berjalan sesuai yang diharapkan.

Namun dengan adanya pembelajaran online menimbulkan banyak kesulitan baik dari sisi guru maupun sisi peserta didik, diantaranya ditemukan oleh Nurdin \& Anhusadar (2020) dalam pelaksanaan pembelajaran daring pada masa pandemic mampu menimbulkan beberapa problem/persoalan, khususnya proses evaluasi pembelajaran pada anak.

\section{Langkah-langkah menghadapi pembelajaran online}

Pelaksanaan pembelajaran online membutuhkan keterampilan dan pengalaman baik pada guru maupun peserta didiknya. Pramana (2020) menjelaskan prosedur yang dilakukan dalam menghadapi pembelajaran di masa pandemi, yakni dengan menghubungkan peran pemerintah, 
institusi yang di dalamnya terdapat guru dan orang tua. Kesuksesan dalam menghadapi situasi ini dijelaskan melalui ketepatan dalam mengambil kebijakan positif dan berdampak baik bagi kelangsungan pendidikan anak usia dini, selain itu pembelajaran dengan jarak jauh menuntut guru untuk memiliki motivasi tinggi dalam menyesuaikan pembelajaran baru yang menggunakan teknologi, selain itu dipengaruhi juga oleh kondisi semangat siswa dalam melaksanakan pembelajaran. Satu hal yang terpenting lagi adalah orang tua yang sigap dengan naik turunnya motivasi belajar anak dan selalu mendampingi serta menjaga kesehatan baik nutsy atau gizi yang baik untuk anak di rumah selama pembelajaran jarak jauh, mengikuti protocol kesehatan serta dukungan lingkungan sekitar.

Dibutuhkan persiapan yang matang oleh pihak sekolah dan orang tua agar pembelajaran online dapat berjalan efektif. Ayuni et al. (2021) mendapati hal yang perlu disiapkan oleh guru dalam pembelajaran daring, seperti berikut: a) Fasilitas berupa kuota internet dan paling penting smartphone, b) Rencana Pelaksanaan Pembelajaran Harian disesuaikan dengan kondisi saat ini atau pandemic covid-19, c) Komunikatif hal yang penting antara guru dan orang tua ketika pembelajaran online, yaitu guru memberi informasi materi pembelajaran, alat dan bahan yang disiapkan di rumah. Hal ini dilakukan agar pembelajaran daring dapat berjalan efektif. Fauziyah (2020) pada hasil penelitian disebutkan bahwa pembelajaran daring akan berjalan dengan efektif jika guru dan anak memahami atau mengerti cara menggunakan teknologi, adanya kepercayaan diri baik guru ataupun anak dalam melakukan pembelajaran sehingga anak selalu termotivasi.

Kim (2020) pembelajaran yang efektif untuk anak usia dini pada masa pendemi covid-19 yang perlu diperhatikan, ialah: 1) guru harus memahami perbedaan anak, 2) guru mengelola kebutuhan anak, 3) melihat gaya belajar anak, kepribadian, dan minat anak, 4) membatasi jumlah interaksi yang dilakukan anak-anak pada masa pandemic covid-19, 5) guru memaksimalkan nilai komunikasi dan baha anak ketika membangun lingkungan sosial, 6) kegiatan pembelajaran dilakukan secara daring seperti menyanyi, menari, menggunting, membuat pola, menggambar, walaupun kesulitan bernyanyi karena jeda suara dalam video tersebut, 7) guru perlu berpikir kreatif dalam merancang pratek perkembangan anak dalam aktivitas secara daring.

Secara global era digital baik lembaga pendidikan ataupun lembaga lainnnya diseluruh dunia mempromosikan pembelajaran secara daring, sehingga pembelajaran tatap muka mengalami penggeseran pembelajaran jarak jauh atau daring (Aldhafeeri \& Khan, 2016). Ditambah lagi adanya virus covid-19 yang terjadi di seluruh dunia. Untuk itu, pemerintah mengamanatkan untuk semua sekolah menghentikan pembelajaran tatap muka dan pembelajaran secara daring yang bertujuan untuk mencegah penyebarluasan covid-19.

Pembelajaran daring ialah pembelajaran melalui internet dimana guru dan anak saling berinteraksi (Singh \& Thurman, 2019). Dong et al., (2020) pembelajaran anak usia dini yang dilakukan pada masa pandemic covid-19 adalah menonton video pembelajaran, menonton langsung di kelas, menggunakan WeChat,menggunakan aplikasi, belajar dengan orang tua langsung, belajar dengan guru. Berdasarkan hasil penelitian Rasmitadila et al., (2020) ada beberapa persiapan yang harus dilakukan guru agar pembalajaran menjadi efektif yaitu strategi pembelajaran yang tepat, kesiapan teknologi yang akan digunakan dalam pembelajaran baik onlineataupun offline, bahan ajar yang digunakan sebaiknya sesuai dengan kondisi serta kebutuhan anak, guru sebaiknya fokus pada materi pembelajaran yang berbeda sebelum adanya covid-19, guru menyelaraskan tujuan pembelajaran dengan kondisi pembelajaran yang baru, keterlibatan orang tua membantu anak untuk memahami materi pembelajaran dari guru, guru memodifikasi pembelajaran dengan menggunakan pendekatan pedadogis, metode pembelajaran yang tepat, sumber daya pendidikan online atau aplikasi, pemerintah Indonesia membuat TV pendidikan dengan program "belajar dari rumah".

Keterlibatan dan partisipasi antara anak, guru, serta orang tua dalam pembelajaran daring sangatlah penting agar pembelajaran menjadi efektif. dengan menggunakan pembelajaran yang efektif akan memberikan motivasi anak untuk menjadi pertisipasi yang aktif dan mengembangkan 
aspek perkembangan anak. Menurut UNESCO (2019) hal yang dapat dilakukan guru atau orang tua ketika mendampingi pembelajaran daring anak, yaitu: 1) terdapat game yang membantu mengembangan aspek perkembangan anak ketika di rumah,, 2) orang tua, keluarga, ataupun guru mendukung dalam memfasilitasi kegiatan bermain sambil belajar di rumah dengan melakukan home visit ke rumah anak, menggunakan pesan, media social dan lain-lain, 3) bermitra dengan Kementerian Pendidikan untuk meningkatkan kualitas melalui televisi ataupun radio, 4) guru mempersiapkan dan merancang pembelajaran jarak jauh.

\section{SIMPULAN}

Orang tua hendaknya memiliki pemahaman mengenai cara belajar anak, membuat lingkungan belajar yang kondusif, menentukan jadwal kegiatan yang bersifat fleksibel namun konsisten. Sebagai pendamping dan motivator dalam pembelajaran, orang tua harus kaya dengan ide-ide bermain, berdiskusi dan mendemonstrasikan materi pembelajaran untuk memudahkan anak mencapai tujuan pembelajaran. Orang tua merupakan perpanjangan tangan dari guru di sekolah sehingga kemampuan yang dimiliki seharusnya setara dengan guru di sekolah selama pembelajaran di masa pandemi. Orang tua sebaiknya memiliki keinginan kuat mengembangkan diri agar dapat mendidik anak selama di rumah. Dengan demikian pembelajaran selama pandemi yang dilaksanakan di rumah dapat berlangsung secara efektif.

\section{DAFTAR PUSTAKA}

Ahsani, E. L. F. (2020). Strategi Orang Tua dalam Mengajar dan Mendidik Anak dalam Pembelajaran At The Home Masa Pandemi Covid-19. Jurnal Al_Athfal, 3(1), 37-46.

Aldhafeeri, F. M., \& Khan, B. H. (2016). Teachers' and Students' Views on E-Learning Readiness in Kuwait's Secondary Public Schools. Journal of Educational Technology Systems, 45(2), 202235. https://doi.org/10.1177/0047239516646747

Anshori, M., \& Iswati, S. (2009). Metodologi Penelitian Kuantitatif. Airlangga University Press.

Ayuni, D., Marini, T., Fauziddin, M., \& Pahrul, Y. (2021). Kesiapan Guru TK Menghadapi Pembelajaran Daring Masa Pandemi Covid-19. Jurnal Obsesi : Jurnal Pendidikan Anak Usia Dini, 5(1), 414-421. https://doi.org/10.31004/obsesi.v5i1.579

Cahyati, N., \& Kusumah, R. (2020). Peran Orang Tua Dalam Menerapkan Pembelajaran Di Rumah Saat Pandemi Covid 19. Jurnal Golden Age, Universitas Hamzanwadi, 4(1), 152-159.

Daulae, T. H. (2014). Menciptakan Pembelajaran yang Efektif. Forum Pedagogik, 6(2), 545.

Dong, C., Cao, S., \& Li, H. (2020). Young children's online learning during COVID-19 pandemic: Chinese parents' beliefs and attitudes. Children and Youth Services Review, 118(June), 105440. https://doi.org/10.1016/j.childyouth.2020.105440

Fauziyah, N. (2020). Dampak Covid-19 Terhadap Efektivitas Pembelajaran Daring Pendidikan Islam. Al-Mau'Izhoh, 2(2), 1-11.

Gayatri, M. (2020). The Implementation Of Early Childhood Education In The Time Of Covid-19 Pandemic: A Systematic Review. Humanities \& Social Sciences Reviews, 8(6), 46-54. https://doi.org/10.18510/hssr.2020.866

Kim, J. (2020). Learning and Teaching Online During Covid-19: Experiences of Student Teachers in an Early Childhood Education Practicum. International Journal of Early Childhood, 52(2), 145-158. https://doi.org/10.1007/s13158-020-00272-6

Lilawati, A. (2020). Peran Orang Tua dalam Mendukung Kegiatan Pembelajaran di Rumah pada Masa Pandemi. Jurnal Obsesi: Jurnal Pendidikan Anak Usia Dini, 5(1), 549. https://doi.org/10.31004/obsesi.v5i1.630

Muhdi, Nurkolis, \& Yuliejantiningsih, Y. (2020). The Implementation of Online Learning in Early Childhood Education During the Covid-19 Pandemic. JPUD - Jurnal Pendidikan Usia Dini, 14(2), 247-261. https://doi.org/10.21009/JPUD.142.04

Nurdin, N., \& Anhusadar, L. (2020). Efektivitas Pembelajaran Online Pendidik PAUD di Tengah Pandemi Covid 19. Jurnal Obsesi: Jurnal Pendidikan Anak Usia Dini, 5(1), 686. https://doi.org/10.31004/obsesi.v5i1.699

Pemerintah Republik Indonesia. (2003). Undang -Undang Republik Indonesia Nomor 20 Tahun 2003. In Pemerintah Republik Indoensia. 
Pramana, C. (2020). Pembelajaran Pendidikan Anak Usia Dini (PAUD) Dimasa Pandemi Covid-19. Indonesian Journal of Early Childhood: Jurnal Dunia Anak Usia Dini, 2(2), 116-124. https://doi.org/10.35473/ijec.v2i2.557

Pudyastuti, A. T., \& Budiningsih, C. A. (2021). Efektivitas Pembelajaran E-Learning pada Guru PAUD Selama Pandemic Covid-19. Jurnal Obsesi: Jurnal Pendidikan Anak Usia Dini, 5(2), 1667-1675. https://doi.org/10.31004/obsesi.v5i2.873

Rahmi, M. (2020). Keefektifan Media Pembelajaran Online Pada Anak Usia Dini Di Masa Pandemi Covid-19. Journal of Chemical Information and Modeling, 3(1), 9-15.

Rasmitadila, R., Aliyyah, R. R., Rachmadtullah, R., Samsudin, A., Syaodih, E., Nurtanto, M., \& Tambunan, A. R. S. (2020). The Perceptions of Primary School Teachers of Online Learning during the COVID-19 Pandemic Period: A Case Study in Indonesia. Journal of Ethnic and Cultural Studies, 7(2), 90. https://doi.org/10.29333/ejecs/388

Rohayani, F. (2020). Menjawab Problematika Yang Dihadapi Anak Usia Dini di Masa. Qawwam: Journal For Gender Mainstreaming, 14(1), 29-50. https://doi.org/10.20414/Qawwam.v14i1.2310

Sari, D. . (2020). Pembelajaran Tatap Muka Dan Daring Terhadap Perkuliahan Mahasiswa/I Teknik Kimia. Prosiding Seminar Nasional Universitas Islam Syekh Yusuf, 1(1), 1364-1369. https://doi.org/10.31219/osf.io/g3d6f

Singh, V., \& Thurman, A. (2019). How Many Ways Can We Define Online Learning? A Systematic Literature Review of Definitions of Online Learning (1988-2018). American Journal of Distance Education, 33(4), 289-306. https://doi.org/10.1080/08923647.2019.1663082

UNESCO. (2019). Play and Early Learning during COVID-19.

Wargadinata, W., Maimunah, I., Dewi, E., \& Rofiq, Z. (2020). Student's Responses on Learning in the Early COVID-19 Pandemic. Tadris: Jurnal Keguruan Dan Ilmu Tarbiyah, 5(1), 141-153. https://doi.org/10.24042/tadris.v5i1.6153

Yulianingsih, W., Suhanadji, S., Nugroho, R., \& Mustakim, M. (2020). Keterlibatan Orangtua dalam Pendampingan Belajar Anak selama Masa Pandemi Covid-19. Jurnal Obsesi: Jurnal Pendidikan Anak Usia Dini, 5(2), 1138-1150. https://doi.org/10.31004/obsesi.v5i2.740

Zed, M. (2014). Metode penelitian kepustakaan (3rd ed.). yayasan pustaka obor inonesia. 